\title{
DESAIN PEMBELAJARAN STATISTIKA MENGGUNAKAN KONTEKS MAL DI KELAS V
}

\author{
Apriana Surya, Zulkardi, dan Somakim \\ Program Pascasarjana Universitas Sriwijaya Palembang \\ Email ${ }^{11}$ : Rianasurya34@yahoo.co.id \\ Email2): zulkardi@yahoo.com \\ Email ${ }^{3)}$ :somakim_math@yahoo.com
}

\begin{abstract}
ABSTRAK
Penelitian ini bertujuan menghasilkan lintasan belajar untuk membantu siswa dalam pembelajaran statistika menggunakan konteks mal di kelas V. Penelitian ini berdasarkan PMRI yang dikaitkan dengan pembelajaran tematik integratif Kurikulum 2013. Metode yang digunakan dalam penelitian ini adalah design research type validation study yang bertujuan untuk membuktikan teori-teori pembelajaran. Penelitian ini dilaksanakan di SD Islam Az-Zahrah Palembang dengan melibatkan siswa kelas V yang berjumlah 24 siswa. Aktivitas-aktivitas pembelajaran yang dilakukan siswa meliputi: 1) membuat turus, 2) menggambar dan menyusun toko baju, 3) memotong dan menyambung batang, 4) menentukan banyak toko baju anak yang sering terdapat di setiap lantai mal, menata ulang susunan toko baju di setiap lantai mal, menentukan toko baju yang terbanyak dan paling sedikit di setiap lantai mal. Hasil dari penelitian ini menunjukkan bahwa melalui serangkaian aktivitas yang telah dilakukan membantu siswa dalam pembelajaran statistika.
\end{abstract}

Kata kunci: statistika, mal, pendekatan PMRI, design research.

\section{ABSTRACT}

This research is purposed to design a learning technique to help the fifth grader of elementary school in statistics through mall context. This research is based on PMRI which is connected to the 2013 integrative learning curriculum. The research uses research design type validation study methodology to validate the learning theories. This research involved 24 students fs Az-Zahrah Islamic elementary school Palembang in fifth grade level. The learning activities conducted by the students are (1) making tally (2) drawing and arranging the clothes store (3) cutting and connecting bar chart (4) designing the clothes stores of every floor, re-arranging the clothes stores on every floor, deciding which floor having less or more stores. The result shown that he aforementioned activities help the students in learning statistics.

Key words: statistics, mall, PMRI approach, research design.

\section{PENDAHULUAN}

Statistika merupakan stepping-stone yang sangat penting untuk mempelajari matematika ke tingkat yang lebih tinggi. Statistika juga sering digunakan dalam kehidupan sehari-hari. Di beberapa negara seperti Amerika Serikat, Jerman dan Australia, siswa telah belajar statistika ketika mereka berada di kelas empat atau lima, atau berusia sekitar sepuluh tahun (ACE, 1991; NCTM, 1989, 2000). Kurikulum di Indonesia, statistika dipelajari mulai dari tingkat dasar kelas IV SD. Sebenarnya, dalam mengajarkan statistika diperlukan media yang dapat mendukung siswa dalam memahami konsep statistika. Seperti yang dikutip oleh Bakker sebagai berikut: 
"Various authors have suggested that studying the history a topic is good preparation for teaching that topic" (Fruedenthal 1983b: Radford 2000: Stanton 2001). "Obstacles that people in the past grappled with are interesting to teachers because students often encounter similar obstacles. However, students also know things people in the past did not know" (Fruedenthal 1983b, p. 1696).

Dari penjelasan di atas dapat diartikan, bahwa berbagai penulis menyarankan untuk menyiapkan materi pelajaran hendaknya menggunakan media. Menurut Centeno at al (1994) kesulitan dalam belajar statistika disebabkan oleh beberapa hal seperti konsep yang sedang dipelajari, pengetahuan awal siswa, serta metode atau pendekatan yang digunakan guru dalam mengajar. Hal ini sejalan dengan Lestariningsih (2010) yang menyatakan bahwa kegiatan belajar mengajar statistika di Indonesia pada umumnya berpusat pada guru (teacher center) tanpa upaya mengembangkan ide-ide matematika siswa melalui interaksi atau diskusi. Hal ini membuat siswa tidak terbiasa dalam mengemukakan ide-ide atau berdiskusi.

Mal adalah sebuah model konkrit yang digunakan dalam mempelajari salah satu materi matematika di kelas V. Rimbey (2008) mengatakan bahwa menggunakan koteks mal dalam mempelajari matematika akan membuat siswa lebih antusias karena di dalam mal tersebut terdapat berbagai jenis pertokoan seperti toko sepatu, toko baju, restaurant, arena bermain dan lain sebagainya.

Menurut Franklin et al, 2007 ada empat langkah dalam menyelesaikan permasalahan statistika, yaitu (1) merumuskan pertanyaan yang dapat dijawab dengan data, (2) mengumpulkan data untuk menjawab pertanyaan, (3) menganalisis data, (4) menginterpretasikan hasil. Berdasarkan teori tersebut, peneliti mengumpulkan data dengan menggunakan konteks mal dimana diharapkan nantinya siswa dapat lebih memahami konsep dari statistika tersebut.

Berdasarkan kurikulum yang dikembangkan di tahun 2013 yang disebut dengan kurikulum 2013, pendekatan PMRI sangat cocok digunakan. Hal ini disebabkan karena pada kurikulum 2013 terdapat pendekatan saintifik dalam pembelajaran yang meliputi mengamati, menanya, mengumpulkan informasi/ mencoba, mengasosiasi/ mengolah informasi, dan mengkomunikasikan.

Berdasarkan pendahuluan tersebut, peneliti akan mendesain pembelajaran materi statistika dengan menggunakan konteks mal melalui pendekatan PMRI di kelas V. Adapun tujuan dari penelitian ini adalah untuk mengetahui peran penggunaan konteks mal dapat membantu siswa memahami konsep statistika di kelas V SD.

Penelitian ini menggunakan pendekatan PMRI. Mathematics must be connected to reality, hal ini berarti bahwa matematika harus diajarkan dengan permasalahan yang menggunakan situasi dalam kehidupan sehari-hari siswa. Situasi bisa berupa segala sesuatu yang bisa dilihat oleh siswa atau semua hal yang bisa dibayangan oleh siswa. Dalam penelitian ini menggunakan Mal karena hal ini bisa dibayangkan oleh siswa.

PMRI memiliki kesamaan karakteristik dengan RME. Treffers (1987), implementasi RME dalam proses pembelajaran matematika memiliki lima karakteristik, yaitu (1) penggunaan konteks, (2) penggunaan model untuk matematika progresif, (3) pemanfaatan hasil konstruksi 
siswa, (4) interaktivitas dan (5) keterkaitan.

Seiring dengan pendekatan PMRI yang pada dasarnya menggunakan situasi dalam kehidupan sehari-hari, maka konteks yang digunakan pada penelitian ini adalah konteks mal. Mal merupakan salah satu jenis pusat perdagangan yang cepat berkembang pesat di kota-kota besar. Dengan adanya mal menunjukkan perkembangan teknologi dari zaman ke zaman. Bagi anak-anak di era sekarang mal bukanlah sesuatu yang asing di telinga mereka khususnya anakanak yang tinggal di daerah perkotaan. Bahkan hampir setiap hari libur mereka mengunjungi mal sebagai salah satu tempat mereka berekreasi, mencari hiburan ataupun berbelanja. Hal tersebut sesuai yang dikatakan Rimbey yaitu:

"You may choose to implement a grade-level or school-wide Math Academy as we originally designed it, or you may prefer to implement these activities in your own classroom. Whichever format you use, keep in mind that the goal is to help your students see the relevance of mathematics in real-life contexts”. (Rimbey, 2008)

\section{METODE}

Penelitian ini menggunakan metode design research pembelajaran. Design research adalah suatu kajian sistematis tentang merancang, mengembangkan dan mengevaluasi intervensi pendidikan (seperti program, strategi dan bahan pembelajaran, produk dan sistem) sebagai solusi untuk memecahkan masalah yang kompleks dalam praktik pendidikan, yang juga bertujuan untuk memajukan pengetahuan kita tentang karakteristik dari intervensiintervensi tersebut serta proses perancangan dan pengembangannya
(Plomp \& Nieveen, 2007). Sedangkan menurut Gravemeijer dan Van Eerde (2009), design research adalah suatu metode penelitian yang bertujuan untuk mengembangkan local instruction theory melalui kerjasama antara peneliti dan guru untuk meningkatkan kualitas pembelajaran.

Dalam design research pembelajaran, proses pelaksanaan penelitian dipandu oleh suatu instrumen yang disebut Hypothetical Learning Trajectory (HLT). Ketika pembelajaran yang dilakukan tidak sesuai dengan desain yang sudah dirancang, maka perlu dilakukan pendesainan kembali (thought experiment) terhadap HLT untuk kemudian dilakukan pengujian kembali terhadap HLT (instruction experiment). Proses ini berlangsung terus menerus tergantung pada waktu dalam melakukan eksperimen. Hubungan refleksi antara Teori dan Percobaan terlihat pada Gambar 1.

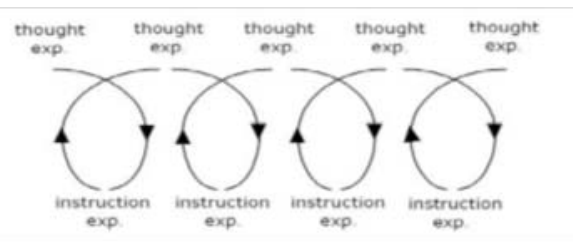

\section{Gambar 1. Hubungan Refleksi antara Teori dan Percobaan}

\section{Tahapan penelitian tersebut adalah:}

1) Preliminary Design

Local Instructional Theory (LIT) yang dilaksanakan pada tahap pertama dalam metodologi sebelum uji coba pembelajaran. Aktivitas dalam LIT adalah melihat aktivitas kerja yang telah direncanakan. Sebelum membuat lintasan belajar, peneliti mempelajari literatur seperti mal dan beberapa buku yang mempelajari statistika. Beberapa literatur yang dibaca akan didedikasikan untuk 
membuat aktivitas statistika dan mengembangkan konteks yang menggunakan mal. Mal dijadikan konteks dengan alasan berada dan tidak terlalu jauh dari lingkungan peserta didik.

\section{2) Design Experiment}

Pada tahap ini, Hypothetical Learning Trajectory (HLT) dielaborasi dan revisi percobaan mengajar. Eksplorasi literatur dan penelitian dilakukan pada waktu tersebut. Selain itu, diujicobakan desain pertama untuk melihat jalannya rencana aktivitas pembelajaran. Dari kegiatan ini, didapatkan masukanmasukan yang mungkin menggantikan serta merivisi dari aktivitas HLT. Uji coba desain dilakukan secara bertahap. Pada tahap pertama yaitu pilot experiment diujicobakan pada kelompok kecil dan peneliti sebagai guru sedangkan guru model mengobservasi pembelajaran yang berlangsung. Peneliti dan guru model mengintrospeksi proses pembelajaran yang berlangsung sehingga dapat menghasilkan aktivitas yang lebih baik. Pada kelas teaching experiment dilakukan pada kelompok besar yang dilakukan oleh guru model. Revisi HLT yang menjadi Learning Trajectory (LT) dilaksanakan pada tahap ini sehingga pola pikir dan strategi peserta didik sangat terlihat dengan menggunakan konteks mal pada materi statistika.

\section{3) Retrospective Analysis}

Peneliti menganalisis apapun yang terjadi pada design experiment. Retrospective Analysis akan dilakukan setelah design experiment dilakukan. Apapun yang terjadi dalam kelas (dilihat dari rekaman video dan lembar observasi) akan dianalisis berdasarkan pada tujuan kita mendesain sehingga dapat diarsipkan atau tidak. Metode atau cara serta strategi peserta didik dideskripsikan.
Menurut Gravemeijer (2004), salah satu tujuan yang hendak dicapai dalam design research adalah mengkombinasikan dua cara yaitu teori pengembangan local instruction dan pengembangan teori kerangka yang meliputi suatu masalah. LIT terdiri dari konjektur atau dugaan yang mungkin dalam proses pembelajaran, sesuatu yang mendukung proses pembelajaran yang berpotensi pada aktivitas peserta didik yang produktif, sesuatu yang dapat dibayangkan di dalam kelas dan guru yang berperan proaktif. Konjektur LIT dimodifikasi dan direvisi berdasarkan pada retrospective analysis setelah teaching experiment. Tujuan pembelajaran dari peserta didik merupakan dari peserta didik merupakan komponen dalam konjektur LIT.

\section{Teknik Pengumpulan Data}

Berdasarkan metode dan prosedur penelitian yang digunakan, maka teknik pengumpulan data yang digunakan dalam penelitian ini adalah (1) tes tertulis, (2) Walk Through, (3) Observasi, (4) Wawancara, (5) rekaman video dan foto, dan (6) catatan lapangan.

\section{Teknik Analisis Data}

Design Research merupakan metode penelitian kualitatif, maka teknik analisis data pada penelitian ini dilakukan secara kualitatif dengan memperhatikan hasil pengumpulan data yang telah dilakukan. Analisis data pada penelitian ini adalah menganalisis hasil tes tertulis siswa, dan membandingkan hasil pengamatan selama proses pembelajaran dengan HLT yang telah didesain. Dalam retrospective analysis peranan HLT yang telah dirancang dibandingkan dengan proses pembelajaran yang dilakukan siswa sehingga dapat dilakukan penyelidikan dan dijelaskan bagaimana siswa dapat memahami konsep statistika. 


\section{HASIL DAN PEMBAHASAN}

Proses pembelajaran yang berlangsung terdiri dari beberapa aktivitas. Sebelum dan sesudah aktivitas dilakukan tes awal dan tes akhir guna mengetahui kemampuan pemahaman konsep peserta didik. Adapun aktivitas yang dilakukan adalah sebagai berikut:

\section{a. Aktivitas 1 “Membuat Turus"}

Aktivitas Peserta Didik:

Peserta didik mengumpulkan data dari sebuah mal, salah satu konteks yang diambil adalah toko baju. Setelah mengumpulkan data siswa akan membuat turus yang digunakan untuk menentukan jumlah toko baju yang ada pada masingmasing lantai yang akan disajikan pada tabel. Selain itu, peserta didik secara berkelompok mempresentasikan hasil lembar aktivitas yang telah dikerjakan dan membuat kesimpulan secara bersama-sama.

Tujuan Pembelajaran:

Peserta didik dapat membuat turus bedasarkan data yang telah mereka kumpulkan. Ketika siswa sudah mampu membuat turus, maka dapat dikatakan siswa telah memahami konsep turus dimana turus digunakan untuk menentukan jumlah dari suatu data. Peserta didik dapat menyimpulkan materi yang telah didapatkan secara bersama-sama dan mendiskusikan hasil aktivitas yang dilakukan pada diskusi besar. Hasil Aktivitas 1 terlihat pada Gambar 2.

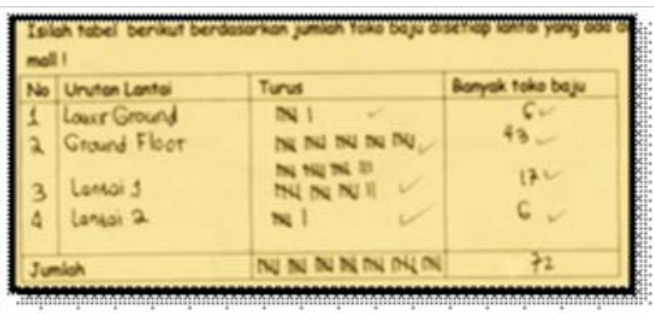

Gambar 2. Jawaban siswa membuat turus
Melihat dari jawaban siswa tersebut, siswa sudah mampu membuat turus. Akan tetapi ada siswa yang yang belum memahami makna dari turus. Siswa membuat terlebih dahulu banyak toko baju kemudian siswa baru membuat turusnya.

Berikut ini merupakan transkrip pada aktivitas 1 pada salah satu kelompok:

Guru : "kenapa kamu menuliskan jumlah terlebih dahulu dari pada turus?”

Siswa : "ya kalau sudah tahu jumlahnya, kan kita baru bisa buat turusnya pak"

Guru : "jadi menurutmu apa kegunaan dari turus tersebut?

Siswa : "untuk menyatakan jumlah dari banyaknya data"

Guru : "ooo jadi jumlah datanya dulu baru kita bisa tahu berapa banyak turus yang akan dibuat?”

Siswa : "iya pak"

Dari tanya jawab antara guru dan siswa tersebut, maka hal tersebut membuktikan bahwa siswa pada dasarnya belum memahami apa kegunaan dari turus tersebut.

\section{b. Menggambar dan Menyusun Toko Baju}

Pada aktivitas 2, peneliti tetap sebagai guru. Guru membagikan LAS 2 yang terdiri dari 3 soal (permasalahan) dan guru memberikan kubus satuan yang digunakan untuk menyusun batang. Siswa masih tetap berdiskusi kelompok seperti pada aktivitas sebelumnya. Siswa diingatkan kembali dengan rekaman dan gambar mengenai banyaknya toko baju yang ada di setiap lantai mal untuk digunakan kembali dalam menggambar dan menyusun diagram batang. Dalam aktivitas ini siswa menggunakan kubus satuan sebagai representasi dari toko baju yang ada di setiap mal. Gambar di bawah ini menunjukkan aktifitas siswa menyusun 
kubus satuan sebelum menggambarkan diagram batang pada diagram cartesius.

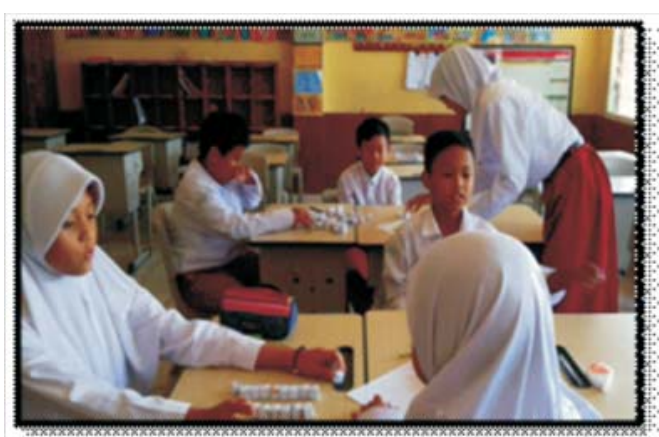

\section{Gambar 3. Siswa bekerja sama menyusunkubus satuan menjadi diagram batang}

Dari aktivitas tersebut siswa menggambarkan susunan kubus tersebut menjadi diagram batang dengan skala tertentu sesuai dengan jumlah toko baju yang ada di setiap lantai mal. Berikut ini merupakan jawaban siswa dari dua kelompok:
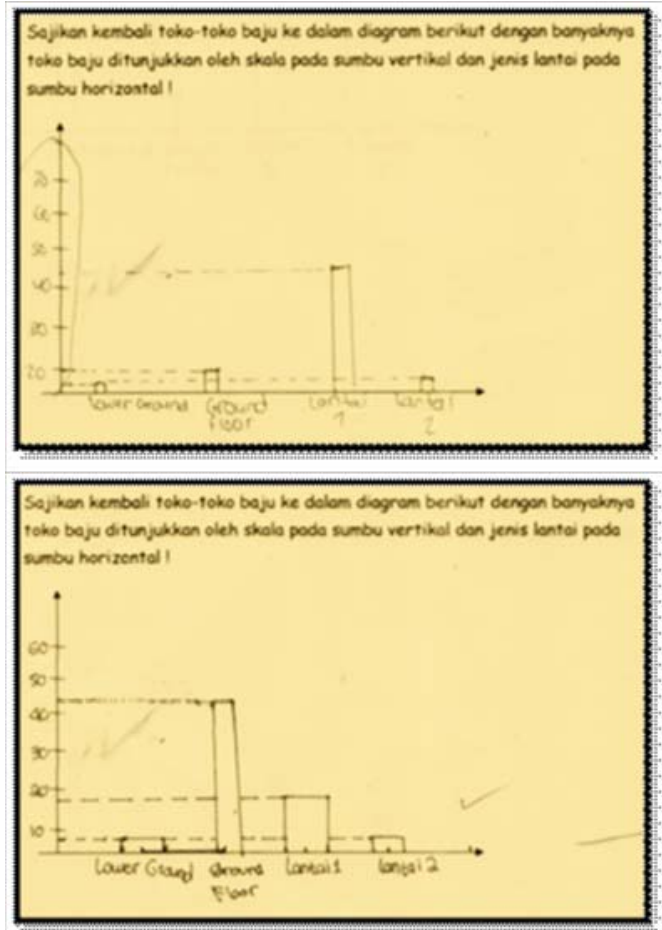

(a)

Gambar 4. Jawaban siswa pada permasalahan membuat diagram batang
Melihat dari jawaban siswa di atas, pada gambar 4 (a) siswa membuat diagram batang dengan menggunakan skala 10 tetapi dimulai dari angka 20. Sedangkan pada gambar 4 (b) siswa membuat diagram batang menggunakan skala 10. Dalam hal ini, tidak ada kesulitan yang terlihat pada siswa saat menyajikan data dalam bentuk diagram batang. Pada soal tersebut sebelumnya siswa diberikan kubus satuan untuk disusun sebagai representasi dari toko baju. Pada saat menyusun kubus tersebut, kedua kelompok tidak menggunakan skala. Akan tetapi pada saat menggambarkan pada diagram batang siswa langsung menggunakan skala. Hal itu menunjukkan bahwa siswa sudah mampu menyajikan data dalam bentuk diagram batang

\section{c. Aktivitas 3}

Dalam aktivitas ketiga, siswa melakukan aktivitas memindahkan potongan batang untuk menemukan konsep rata-rata. Dengan menggunakan kubus satuan, siswa menyusun kubus tersebut berdasarkan data jumlah toko baju yang ada di setiap lantai mal kemudian siswa diminta untuk menyamakan tinggi dari susunan kubus tersebut.

Gambar 5(a) dan (b) merupakan jawaban dari beberapa siswa:

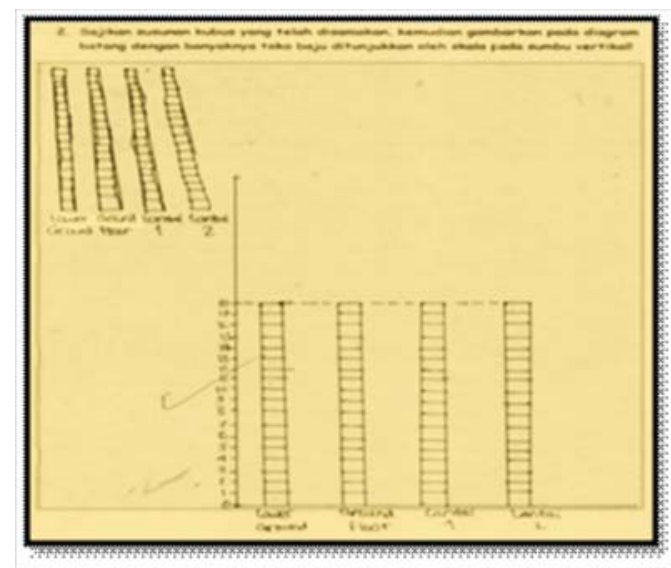

(a) 


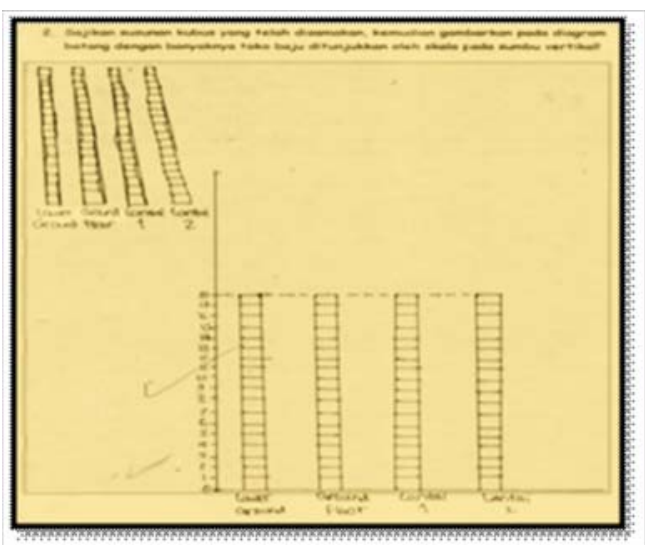

(b)

Gambar 5. Siswa menggambarkan susunan kubus yang telah disamakan ke diagram cartesius

Melihat jawaban siswa tersebut, siswa menyamakan tinggi batang pada diagram cartesius. Ada beberapa cara yang dilakukan siswa, diantaranya siswa menyamakan tinggi batang kubus satuan dengan cara memindahkan dari batang yang lebih tinggi ke batang yang lebih rendah. Pada kelompok lain, siswa langsung menjumlahkan toko baju kemudian baru dibagi dengan banyaknya lantai sehingga didapat tinggi batang yang sama.

Gambar 6. merupakan aktivitas siswa dalam menyamakan tinggi batang menggunakan kubus satuan:

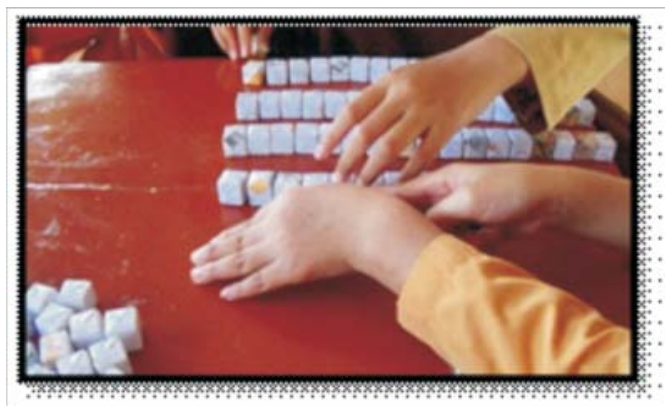

Gambar 6. Aktivitas siswa menyamakan tinggi batang menggunakan satuan kubus

\section{d. Aktivitas 4 dan 5}

Pada aktivitas 4 dan 5 siswa masih menggunakan kubus satuan sebagai representasi dari toko baju yang ada di mal untuk menemukan konsep modus, urutan data, nilai tertinggi dan nilai terendah. Siswa masih menggunakan kubus satuan sebagai representasi dari toko baju yang disusun berdasarkan jumlahnya kemudian siswa menentukan dilantai mana yang paling sering menjual baju anak. Setelah itu sisa mengurutkan jumlah dari mulai yang terkecil hingga terbesar yang secara tidak langsung siswa langsung bisa menemukan nilai tertinggi dan nilai terendah. Pada saat pembelajaran terdapat berbagai macam jawaban siswa yang terlihat pada Gambar 7.:

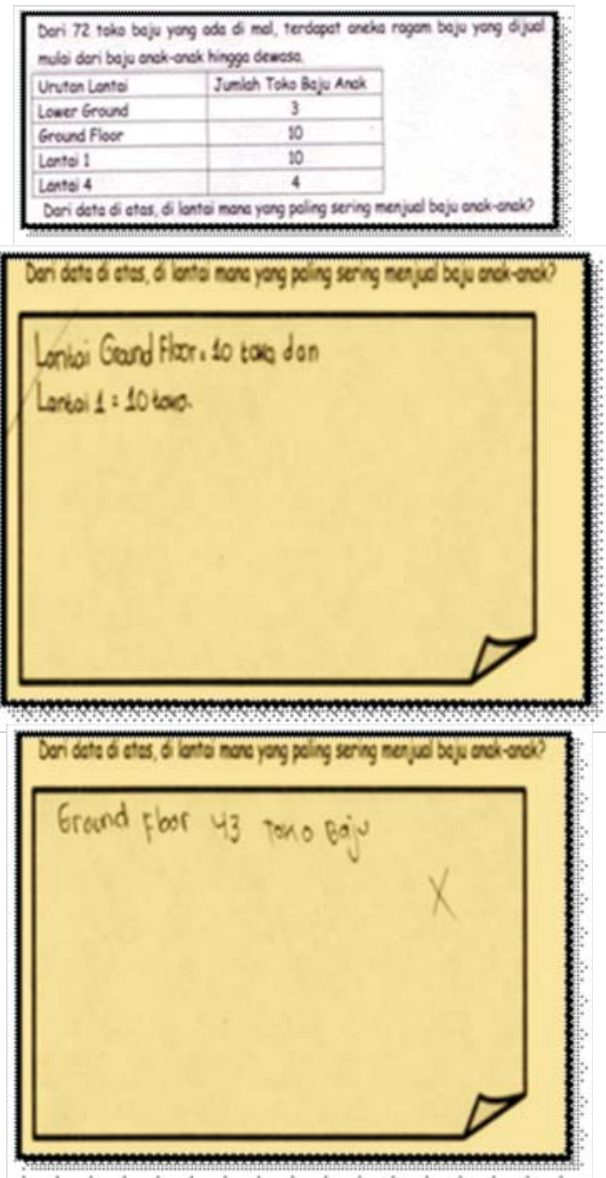

Gambar 7. Jawaban siswa pada soal menentukan modus 
Untuk menemukan nilai modus, ada siswa yang menjawab dengan benar. Akan tetapi ada siswa yang memahami nilai modus sebagai nilai yang paling besar. Pada saat menjawab soal urutan data, ada siswa yang belum memahami makna dari mengurutkan data dari yang terkecil hingga nilai yang terbesar. Dari hasil jawabannya siswa memaknai bahwa ketika menemukan angka yang nilainya sama maka dianggap satu kali saja yang mewakili. Data toko baju yang di setiap lantai mal adalah (1) lower ground berjumlah 6, (2) ground floor berjumlah 16, (3) lantai 1 berjumlah 44, (4) lantai 2 berjumlah 6. Gambar 8. merupakan jawaban yang salah pada saat menentukan urutan nilai dari yang terbesar hingga yang terkecil:

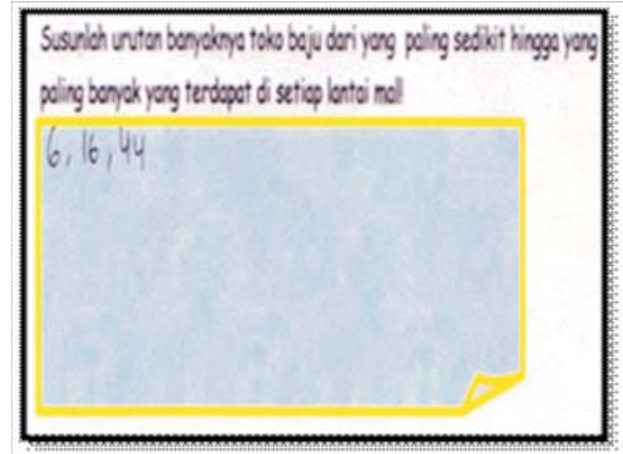

\section{Gambar 8. Jawaban siswa pada soal menentukan urutan data}

Untuk mendukung konteks tersebut maka pendekatan PMRI berperan sangat besar dalam proses pembelajaran yang berlangsung lebih efektif dan efisien. Pendekatan PMRI, serangkaian urutan kegiatan dan konsep statistika menjadi acuan utama dalam setiap aktivitas pembelajaran yang telah dilaksanakan pada setiap siklus.

Aktivitas pertama menunjukkan bahwa siswa mengeksplorasi pengetahuan awal melalui kegiatan mengumpulkan data toko baju yang ada di setiap lantai kemudian membuat turus untuk disajikan dalam diagram batang. Saat proses pembelajaran, siswa sangat antusias menghitung jumlah toko baju yang ada di mal. Pendesainan aktivitas ini mengacu pada karakteristik PMRI yakni pembelajaran harus diawali dengan penggunaan konteks yang bertujuan untuk meningkatkan motivasi dan ketertarikan siswa dalam belajar (de Lange dalam wijaya, 2012). Aktivitas ini mengacu pada statistika sebagai bagian dari keseluruhan. Gambar 9. merupakan aktivitas anak menghitung jumlah toko baju yang terdapat di dalam mal:

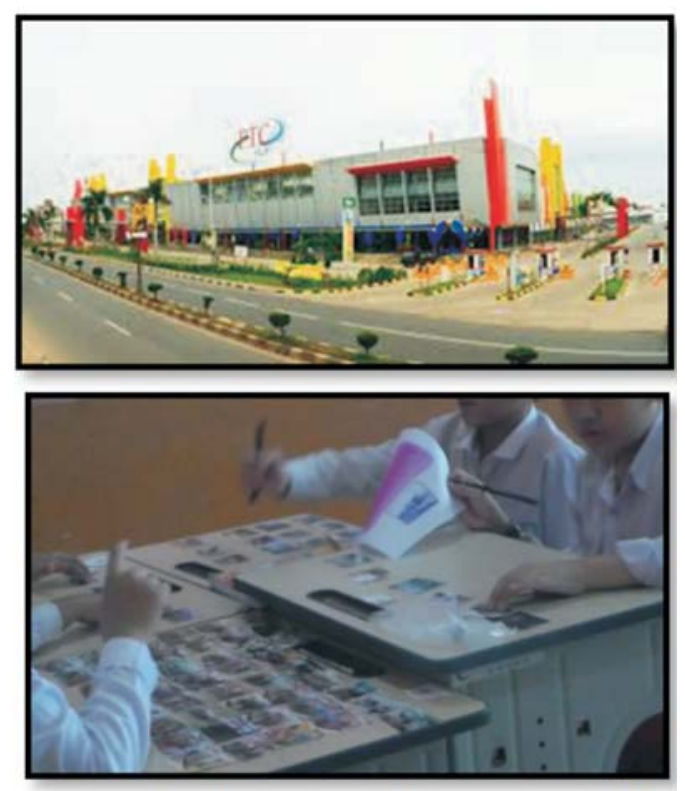

Gambar 9. Siswa menghitung jumlah toko baju pada masing-masing lantai mal

Aktivitas kedua, siswa diarahkan untuk menggambarkan diagram batang dari susunan kubus yang telah mereka rancang berdasarkan data yang telah mereka miliki. Pada saat menggambar diagram batang tersebut, ditemukan beberapa macam strategi siswa dalam menyajikan data pada diagram batang. Diantaranya ada kelompok yang menggambarkan diagram batang 
menggunakan skala satuan, sehingga pada saat menemukan angka yang nilainya besar angka satuang yang terdapat pada sumbu vertikal menjulang tinggi. Selain itu ada juga kelompok yang menggambarkan diagram batang menggunakan skala 2 dan 5 sehingga 1 kotak kubus mewakili angka 2 dan 5. Hal itu menunjukkan bahwa siswa mampu berfikir rasional pada saat menggambarkan diagram batang. Akan tetapi, ada juga kelompok yang menggambarkan diagram batang terbalik, dimana jenis lantai terdapat pada sumbu vertikal sedangkan yang menunjukkan jumlah toko pada sumbu horizontal. Dalam hal ini, guru model menggiring siswa untuk menggambar diagram batang tersebut dengan pemahaman yang benar.

Gambar 10. merupakan aktivitas siswa dalam menyusun kubus satuan sebagai representasi dari toko baju yang terdapat di mal:

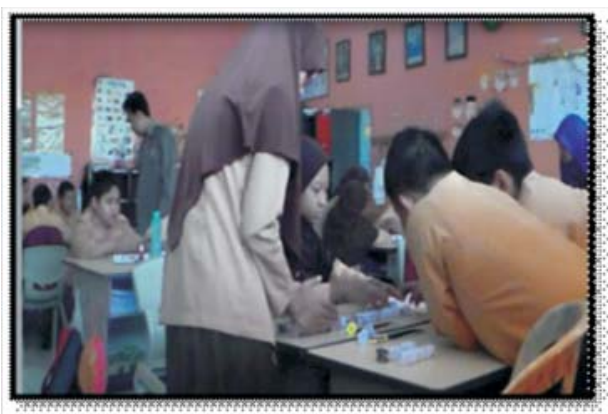

Gambar 10. Aktivitas siswa menyusun kubus satuan menjadi diagram batang

Aktivitas ketiga yang merupakan arah tahap formal, siswa diarahkan dan dibimbing untuk memotong dan menyambung batang dari susunan kubus. Dari kegiatan tersebut, kelompok melakukan aktivitas tersebut dengan terlebih dahulu memnyusun kubus satuan berdasarkan jumlah data yang telah mereka miliki. Dari aktivitas tersebut, ada kelompok terlebih dahulu menyusun kubus berdasarkan jumlah data kemudian mereka menyamakan tingginya dengan cara memindahkan kubus tersebut sehingga tinggi batang menjadi sama. Pada kelompok lain menunjukkan bahwa ketika mereka telah menyusun kubus satuan tersebut, siswa menjumlahkan semua jumlah kubus kemudian dibagi berdasarkan banyaknya lantai. Ada juga kelompok lain tanpa menggunakan kubus, mereka langsung menjumlahkan toko baju kemudian dibagi berdasarkan banyaknya lantai. Dari kegiatan tersebut, siswa digiring untuk memahami konsep rata-rata dengan benar. Secara umum pembelajaran berlangsung interaktif karena siswa berdiskusi. Hadi (2005) menyatakan pembelajaran matematika dengan pendekatan PMRI pengajaran berlangsung secara interaktif, siswa menjelaskan dan memberikan alasan terhadap jawaban yang diberikannya, memahami jawaban temannya, setuju terhadap jawaban temannya, menyatakan ketidaksetujuan, mencari alternatif penyelesaian yang lain dan melakukan refleksi terhadap setiap langkah yang ditempuh atau terhadap hasil pelajaran.

Gambar 11. merupakan aktivitas siswa mengubah tinggi batang menjadi sama:

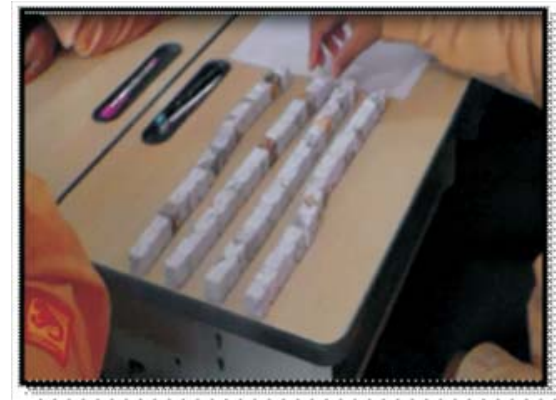

Gambar 11. Aktivitas siswa mengubah tinggi batang menjadi sama

Pada aktivitas keempat, siswa menyusun kembali jumlah toko baju 
berdasarkan lantai dengan menggunakan kubus satuan. Kemudian siswa mampu menentukan mana toko baju yang paling serimg terdapat disetiap lantai mal sehingga secara tidak langsung siswa dapat menemukan modus. Selain itu siswa sekaligus mengurutkan data sehingga ditemukan mana nilai tertinggi dan nilai terendah. Pada kegiatan ini, ada kelompok yang menganggap bahwa menentukan nilai modus itu adalah nilai yang paling besar. Kemudian pada saat mengurutkan data, ada kelompok yang menuliskan urutan data belum tepat karena ketika menemukan angka yang nominalnya sama mereka hanya menuliskan satu kali.

Proses pembelajaran berlangsung menggunakan Lembar Aktivitas Siswa (LAS) yang dalam penelitian ini adalah lembar aktivitas. Penggunaan LAS membantu dan mempercepat proses pembelajaran, hal ini sesuai pendapat Muzayyanah (2009) bahwa kegunaan LAS salah satu alternatif bagi guru untuk mengarahkan pengajaran, dapat mempercepat proses pembelajaran, dapat mempermudah penyelesaian bagi perorangan atau kelompok kecil dan dapat meningkatkan kerja guru dalam memberikan bantuan atau mendidik, terutama untuk mengelolah kelas.

Kegiatan penutup pembelajaran adalah siswa maju mempresentasikan hasil diskusi atau aktivitas yang mereka lakukan. Presentasi memberikan kesempatan siswa untuk mengungkapkan pendapat mereka sehingga mereka dihargai dan akhirnya akan merasa senang mengikuti pembelajaran (Suherman, 2003: 261; Muzayyanah, 2009). Siswa yang presentasi memiliki kesempatan mengemukakan dan mempertahankan pendapat mereka.
Gambar 12. adalah salah satu kegiatan presentasi siswa di depan kelas:

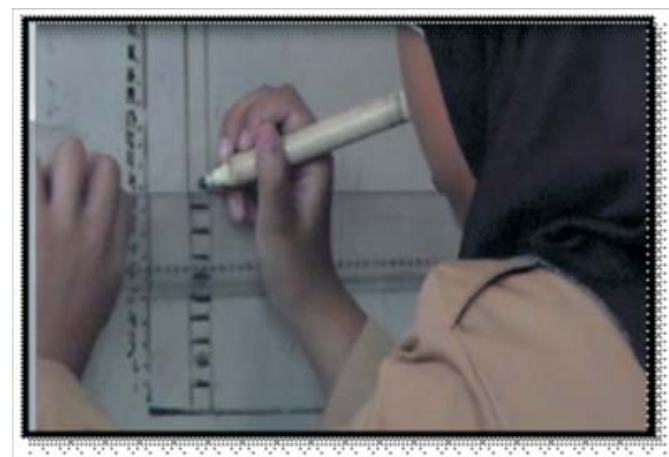

\section{Gambar 12. siswa mempresentasikan} hasil jawaban kelompknya

Sebelum dan sesudah melakukan serangkaian aktivitas pembelajaran, siswa diberikan pretest dan postest. Dari kedua tes ini, peneliti memperoleh informasi bahwa hasil pekerjaan siswa menunjukkan ada perbedaan antara pretest dan postest dalam memahami statistika. Melalui empat aktivitas yang didesain mampu membuat pengetahuan siswa bertambah dalam menyelesaikan masalah tentang statistika. Dengan demikian penemuanpenemuan di dalam penelitian ini merupakan bagian yang tidak terpisahkan dari pengembangan local instructional theory dalam hal ini pendekatan PMRI dalam pembelajaran materi statistika.

Selanjutnya di dalam pembelajaran ini berdasarkan implementasi PMRI dalam pendesainannya yang menunjukkan bagaimana karakteristik PMRI menjadi dasar pada setiap aktivitasnya. Lima karakteristik PMRI yang merupakan adopsi dari RME menurut Treffers (1987) pada hubungannya dalam pembelajaran ini akan dijelaskan sebagai berikut:

Karakteristik yang pertama adalah the use of context atau penggunaan konteks dimana kegiatan pembelajaran dimulai dengan penggunaan masalah kontekstual. Dalam hal 
ini masalah kontekstual yang digunakan adalah penggunaan mal yang di dalamnya terdapat toko baju untuk memahami konsep awal mencari data. Gambar 13 merupakan konteks yang digunakan.

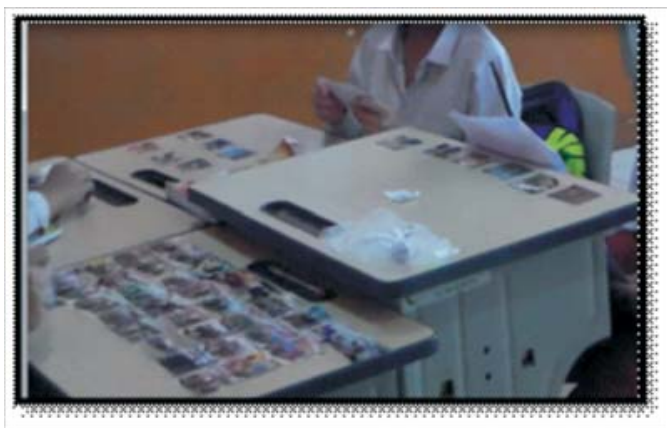

Gambar 13. Penggunaan konteks mal

Karakteristik yang kedua adalah using models and symbols for progressive mathematization atau penggunaan model dimana menggunakan model bertujuan untuk menghubungkan antara sesuatu yang kongkrit menuju sesuatu yang abstrak atau antara level informal menuju level yang lebih formal. Terdapat empat macam level dalam pembelajaran PMRI yaitu situations (situasional), model of (referensial), model for (general), dan formal (Gravemeijer, 1994). Penggunaan kubus satuan yang merupakan representasi dari toko baju merupakan level situasioanl dimana peneliti menggunakan konteks yang disajikan dalam proses pembelajaran. Siswa kemudian menggunakan mal dimana di dalam mal terdapat toko baju yang direpresentasikan dengan menggunakan kubus. Gambar 14 merupakan presentasi mal dengan kubus.

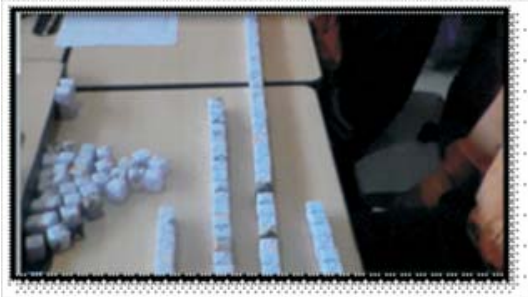

Gambar 14. Kubus satuan sebagai model konkrit
Karakteristik yang ketiga adalah using student's own contribution and production. Pemanfaatan hasil kontruksi siswa terlihat sejak proses pelaksanaan dari aktivitas 1-3 dimana guru menghargai setiap jawaban dan kontribusi siswa yang muncul selama proses pembelajaran. Guru memberikan kebebasan siswa dalam mengungkapkan dan menjawab pertanyaan dengan menggunakan strategi mereka masing-masing. Banyaknya variasi jawaban siswa membuat pembelajaran matematika menjadi lebih menarik karena akan muncul diskusi kelas. Para siswa menentukan strategi mana yang terbaik untuk mereka gunakan. Gambar 15 merupakan strategi siswa menyelesaikan masalah.

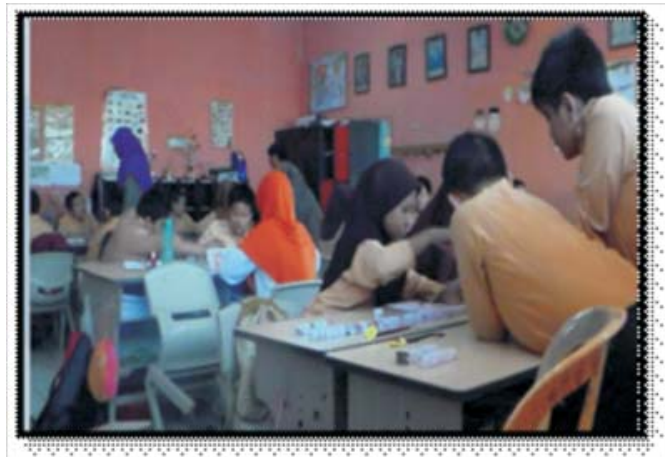

Gambar 15. Salah satu strategi siswa dalam menyelesaikan masalah

Karakteristik yang keempat adalah interactivity. Pada proses pembelajaran baik pada siklus 1 dan siklus 2, interaktivitas tidak hanya terjadi antara guru dan siswa tetapi juga dengan sesama siswa. Bentuk interaksi dapat berupa diskusi, memberikan penjelasan, komunikasi, kooperatif dan evaluasi. Interaksi antara guru dan siswa terlihat pada saat proses pembimbingan kepada semua kelompok yang dapat dilihat dalam dialog-dialog pada hasil penelitian. Walaupun tidak semua kelompok mendapatkan bimbingan dari guru namun beberapa kelompok telah dibantu oleh peneliti untuk berdiskusi. 
Sementara itu, aktivitas sesama siswa telah berlangsung dengan baik namun pada saat proses pembelajaran. Dengan demikian setelah terjadinya proses sosial, siswa dapat menemukan sendiri pemahamannya mengenai statistika. Gambar 16 merupakan interaktivitas siswa.

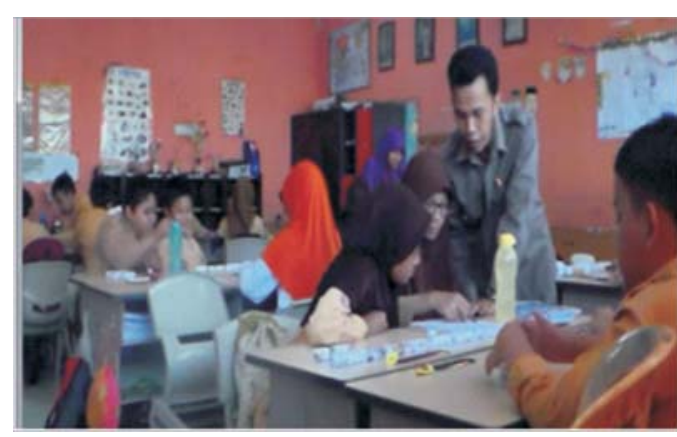

Gambar 16. salah satu bentuk interaktivitas siswa

Karakteristik yang terakhir adalah intertwinement (keterkaitan). Pada pembelajaran ini tidak terlepas dari konsep penjumlahan, pembagian, dan perbandingan suatu benda.

Penelitian ini juga mencerminkan tiga prinsip PMRI pada proses pembelajaran. Ketiga prinsip tersebut dijelaskan sebagai berikut: prinsip pertama adalah guided reinvention and progressive mathematizing. Berdasarkan prinsip guided reinvention, siswa dalam proses pembelajaran statistika diberikan kesempatan untuk mengalami proses yang sama mengenai konsep matematika ditemukan melalui bimbingan guru dengan penggunaan representasi toko baju. Prinsip kedua adalah didactical phenomenology dari konsep matematika adalah sebuah analisis yang dilakukan pada konsep matematika dan dihubungkan dengan fenomena menarik yang lain. Tantangan dalam prinsip ini yaitu menemukan fenomena yang bisa dihubungkan dengan konsep matematika. Dalam penelitian ini, konteks mal digunakan sebagai fenomena dalam pembelajaran konsep awal mengumpulkan data. Selanjutnya prinsip ketiga adalah selfdeveloped models. Peran prinsip ini merupakan jembatan bagi siswa dari situasi real ke situasi konkrit atau dari informal ke formal matematika. Artinya siswa mengembangkan model dari situasi informal menuju ke formal.

\section{SIMPULAN}

Design Research merupakan pengembangan LIT pada pola bilangan yang mendesain kegiatan-kegiatan sehingga membantu peserta didik dalam mempelajari statistika. Konteks mal sehingga mempunyai kekuatan yang dapat merepresentasikan pikiran peserta didik dalam menentukan strategi yang digunakan. Pembelajaran statistika menngunakan konteks yang nyata sehingga diharapkan dapat membantu dalam mengembangkan strategi berfikir peserta didik untuk mengemukakan ide atau gagasan dalam menyelesaikan pemecahan masalah.

\section{DAFTAR PUSTAKA}

ACE. (1991). A national statement on Mathematics for Australian School. Carlton, Vic, Australia: Curriculum Corporation.

Batanero , Godino, Green, Holmes dan Vallecillos. (1994). Errors and Difficulties in Understanding Statistical Concepts. International Journal of Mathematics Education in Science and Technology, 25 (4), 527-547.

Freudenthal, H. (1983a). Didactical Phenomenology of Mathematical Structures. Dordrecht: Raidel

Gravemeijer, K. \& Van Eerde, D. (2009). Design Research as a Means for Building a Knowledge Base for Teacher and Teaching in 
Mathematics Education. The Elementary School Journal 109 (5), 510-524.

Lestariningsih. (2010). Desain Pembelajaran Matematika Legenda Pulau Kemaro pada Pembelajaran Statistika di Kelas VI Sekolah Dasar. Prosiding Seminar Nasional Pendidikan 2012. pp 215-224.

Rimbey, Kimberly. (2008). Math Academy Lets Go to The Mall. New York: Towers Perrin.

Treffres, A. (1987). Three Dimensions. A Model of Goal and Theory Description in Matematics Instruction - The Wiskobas Project. Dordrecht, The Netherlands: Reidel Publishing Company.

Wijaya, Ariadi. (2012). Pendidikan Matematika Realistik Suatu Alternatif Pendekatan Pembelajaran Matematika. Yogyakarta: Graha Ilmu. 